\title{
Causes, Consequences and Ways of Financing the Budget Deficit
}

\author{
Ramona Mariana Calinica \\ ramona.calinica@ugal.ro \\ "Dunarea de Jos" University of Galati, Romania
}

\begin{abstract}
In recent decades the budget deficit has become an increasingly common and pronounced feature of the economies of different countries in the world economy. The purpose of this article is to identify the causes, consequences and ways of financing the budget deficit and to analyze the evolution of this indicator in Romania compared to the average of the European Union and the Euro Zone, between 2009-2018.
\end{abstract}

Keywords: budget deficit, financing, Government debts

\section{Introduction}

In the specialty literature the notion of budget deficit is explained, as the situation in which the budgetary expenses exceed the revenues. The public financial imbalance is the result of too high demand for public financial resources, compared to the funds that can be set up at the state level. Therefore, to express this gap in value, the term budget deficit is most often used. A budget deficit is of quality when it meets two mandatory conditions: the deficit is fully reflected in investment expenditure and, in particular, in the construction of the infrastructure; the deficit is covered by secure financial resources, in order not to resort to inflationary monetary issues. [4].

\section{The budget deficit. Definition, concept and characteristics}

The budget deficit is defined as a sin, it is perceived as something morally wrong, very difficult to avoid, not always easy to identify and quite difficult to measure accurately [3].

Some experts believe that the budget deficit is not a well defined concept in economics literature, but rather a number whose value depends on how certain budgetary operations are treated, in terms of registration, [1].

The total deficit recorded (registered) in one year may be divided into two components, as follows [5]:

a) structural deficit - occurs when the cyclically adjusted budget is in deficit. The cyclically adjusted budget refers to an economy that ensures full use of labor and represents the budget deficit / surplus that will exist if the economy ensures full use of labor (when the national income obtained is equal to the potential national income);

b) cyclical deficit - is defined as the total budget deficit minus the structural deficit and being represented by the relation: Total budget deficit $=$ Structural deficit + Cyclical deficit.

By studying the definitions above, it can be specified that the budget deficit is located in the opposite plane of the budget surplus situation, which is otherwise recorded when the tax revenues are higher than the public expenses.

\section{Causes, consequences and ways of financing the budget deficit}

The causes of the budget deficits can be generated by internal factors but also by the international situation and can cause the occurrence of this phenomenon both in countries with developed economy, as well as in countries with developing economy or in transition. Broadly, as identified in the literature, these causes are as follows [6]:

- high costs with maintenance of government apparatus;

- debt repayment expenses; 
- high costs of arming in most countries and, in general, all kinds of unproductive expenditure.

- low budget revenues as a result of a low tax base;

- high expenses for the administrative apparatus.

- decrease of the level of production and, implicitly, of the gross domestic product;

- a significant increase in the inflation rate;

Usually, reducing the budget deficit requires a reduction in spending, an increase in revenue or a combination of these two situations. But very important is that any increase or decrease in the level of taxes must be studied in the light of long-term and short-term effects, as this level will have an influence on both the supply of funds saved and the demand for such funds having to be taken into account and the need for a comprehensive use of resources on the basis of non-inflationary economic growth.

In time, economists' views on the effects of the budget deficit on the economic performance of a state were linked to two main approaches. On the one hand, it was considered that deficits resulting from the reduction the marginal tax rates have a stimulating effect on the productive workforce. On the other hand, budget deficits were considered a cause of economic stagnation and its instability [7].

The effects of the budget deficit may include, among others: an increase in the future of fees and taxes, an increase in public debt, the demand for public loans, interest and related commissions, a decrease in the saving rate and the growth rate.

The increase of the market interest rate has the effect of restricting the demand for loans addressed by the economic agents and implicitly reducing the investments made on credit. The reduced private investments contribute to the decrease of the labor productivity and implicitly to the reduction of the wages. Also, the loans made by private individuals are diminished in order to purchase long-term goods or to build and buy housing. At the same time, the decrease in private consumption is registered, because a high interest rate encourages savings. [8]

Figure 1. Methods of financing the budget deficit
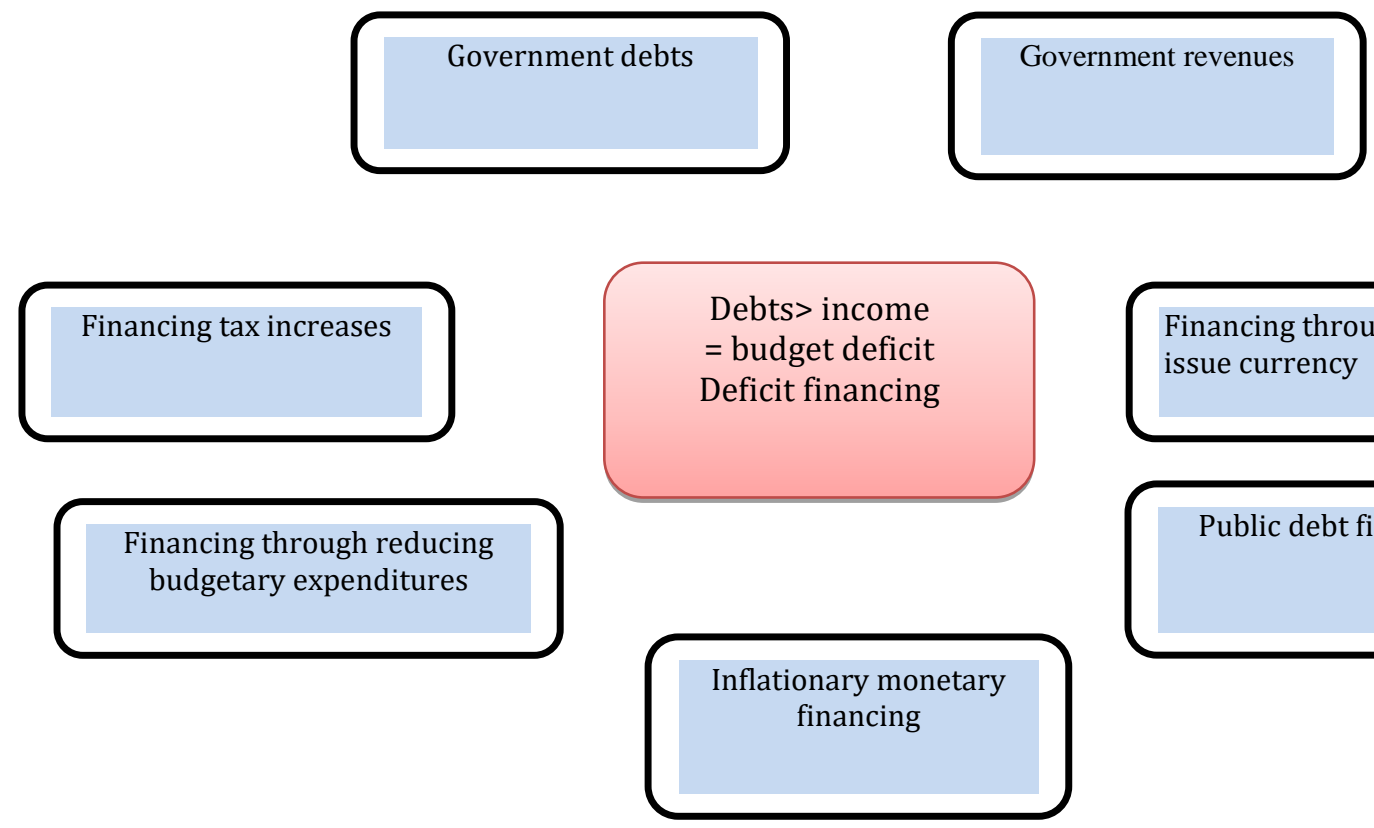

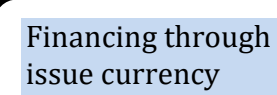

issue currency

Public debt financing

Source: [2]

3. The evolution of the budget deficit in Romania compared to the average of the European Union and the Euro Zone 
In recent years, according to Eurostat, the budget deficit has dropped dramatically. Both in the euro area and in the European Union, the deficit has decreased three and a half times. Which shows that all European states, with some exceptions, have strongly adjusted their budget deficit against the backdrop of economic growth. European economies have taken advantage of GDP expansion to strengthen their budgetary situation. Here we are talking about the nominal values of the deficit, which do not necessarily take into account the GDP growth, but only the adjustments that economies and budgets have managed to make. Unfortunately, at the chapter where Romania has always had problems, either because of the structure of the economy, or for reasons related to fees and taxes with a low share, or because of tax evasion. And in 2018, the performance remains poor, meaning that the level of budgetary revenues is $32 \%$ of GDP, compared to an average of $45 \%$ of GDP, and that of expenditures reaches $35 \%$ of GDP, compared to the European average of $45.6 \%$ of GDP [10].

The budget deficit as a share of GDP in the Euro Zone registered a continuous decrease during the analyzed period, from $-6.6 \%$ of GDP recorded in 2009 to $-0.5 \%$ of GDP in 2018 . The same trend has also been maintained in Romania, but only until 2015, there was a decrease from $9.1 \%$ in 2009 to $-0.7 \%$ in 2015 , followed by a deepening of it to the level of $-2,7 \%$ in 2016 and 2017 and $-3 \%$ in 2018. At the level of the whole European Union, as in the case of the Euro Zone, there was a continuous decrease during the analyzed period, from the level of $-6.6 \%$ in 2009 to $-0.6 \%$ in 2018. Romania has registered values above the level average registered in the EU and the Euro Zone in the years 2009, 2010, 2011, 2016, 2017, 2018 and it can be observed that in 2018 the gap is large: $3 \%$ in Romania compared to $-0.6 \%$ the European Union average and $-0,5 \%$ of the Euro Zone.

Table 1. Budget deficit (\% of GDP)

\begin{tabular}{|c|l|l|l|l|l|l|l|l|l|l|}
\hline & $\begin{array}{l}200 \\
9\end{array}$ & $\begin{array}{l}201 \\
0\end{array}$ & $\begin{array}{l}201 \\
1\end{array}$ & 2012 & 2013 & 2014 & 2015 & 2016 & 2017 & 2018 \\
\hline $\begin{array}{c}\text { European Union } \\
-28 \text { countries }\end{array}$ & 6.6 & 6.4 & 4.6 & 4.3 & 3.3 & 2.9 & 2.3 & 1.7 & 1.0 & 0.6 \\
\hline $\begin{array}{c}\text { Euro area (19 } \\
\text { countries) }\end{array}$ & 6.2 & 6.2 & 4.2 & 3.7 & 3.1 & 2.5 & 2.0 & 1.6 & 1.0 & 0.5 \\
\hline Romania & 9.1 & 6.9 & 5.4 & 3.7 & 2.2 & 1.3 & 0.7 & 2.7 & 2.7 & 3.0 \\
\hline
\end{tabular}

Source: Eurostat [9]

Although, with the exception of 2016, in Romania the level of incomes increased during the analyzed period, nevertheless they were below the expenses level that registered a continuous and accelerated growth. Thus, compared to 2013, the expenses increased from 50916.9 million euros to 71067.7 million in 2018 , ie by $39.57 \%$, and the revenues from 47824.5 million euros to $64946.6 \%$ euros, in relative terms to $3580 \%$.

Table 2. Evolution of the synthetic budgetary indicators in Romania between 2013 and 2018

\begin{tabular}{|c|c|c|c|c|c|c|}
\hline \multirow{2}{*}{ Indicators } & \multicolumn{7}{|c|}{ Milioane euro } \\
\cline { 2 - 7 } & $\mathbf{2 0 1 3}$ & $\mathbf{2 0 1 4}$ & $\mathbf{2 0 1 5}$ & $\mathbf{2 0 1 6}$ & $\mathbf{2 0 1 7}$ & $\mathbf{2 0 1 8}$ \\
\hline Incomes & 47824,5 & 51269,8 & 56786,5 & 54229 & 58001,4 & 64946,6 \\
\hline Expenditures & 50916,9 & 53157,3 & 57900,3 & 58850,1 & 63059,8 & 71069,7 \\
\hline
\end{tabular}

Source: Eurostat[9] 
In the event of a budget deficit the most important issue is not the existence itself of the deficit, but its size relative to GDP. Also very important are the ways that can be financed so as not disrupted economic and social activities.

\section{Conclusions}

The budget deficit has become a characteristic phenomenon of the contemporary world and certainly reflects the economic situation of a country. An increase in the budget deficit and its location at a high level can cause large macroeconomic imbalances, including an increase in the inflation rate, foreign debt, the depreciation of the national currency and many other phenomena with negative impact on the national economy.

Budget deficit problem can occur both in economically developed countries and countries with economies in developing or in transition, and the causes can be both endogenous and exogenous nature.

In the economies of the various states it is necessary to adjust the public expenditure to the level of public revenues, and if this goal was not achieved then solutions must be found to finance the created budget deficit.

\section{References}

1. Auerbach, A.J.; Gokbale, J.; Kotlikoff, L.J. (1994), „Generational Accounting: A Meaningful Way to Evaluate Fiscal Policy", Journal of Economic Perspectives, Vol. 8, No.1, p. 73-94

2. Băcescu-Cărbunaru, A., „Macroeconomie si politici macroeconomice”, Editura All Educational, 1998, p. 216

3. Eisner, R. (1984), „Which Budget Deficit? Some Issues of Measurement and their Implications”, The American Economic Review, Vol. 74, No.2, May 1984, p. 138

4. Kiritescu, C., "Moneda. Mică enciclopedie”, Ed. Ştiintifică şi Enciclopedică, Bucureşti, 1982, p. 23

5. Moșteanu T., "Politici fiscale și bugetare pentru reformarea economiei și relansarea creșterii economice", Ed. Economică, București, 2003, p. 202-203

6. Moșteanu, T.,Câmpeanu, E., Panaite, A. I., Stoian, A., Țâtu, L., Cataramă, D., Brassoveanu, I., Tudor, R., György, A., Miricescu, E., Finanțe publice, Ed. Universitară, Bucureşti, 2005

7. Romer, D., „What Are the Costs of Excessive Deficits?”, NBER Macroeconomic Annual, 1988, Cambridge, p. 63

8. Văcărel Iulian, Bistriceanu, G.D, Bercea, F., Anghelache, G., Mosteanu, T., Bodnar, M., "Finante publice", Ediția a V-a, Ed. Didactică și Pedagogică, București, 2006, p. 521

9. https: / / ec.europa.eu/ eurostat/data/ database

10. bttps:// wnw.rfi.ro/economie 